\title{
"PENGARUH PARTISIPASI MASYARAKAT DAN MOTIVASI TERHADAP TINGKAT KEBERHASILAN RURAL INFRASTRUKTUR SUPPORT- PROGRAM NASIONAL PEMBERDAYAAN MASYARAKAT (RIS-PNPM) MANDIRI DI DESA WARINGIN SARI PRINGSEWU"
}

\section{"The Effect Of Participation Of Community And Motivation To The Level of Success in RIS-PNPM Waringin Sari Village Pringsewu"}

\author{
Fajar Mutia Suri, S.E., M.M. \\ Jurusan Administrasi Niaga, Universitas Tulang Bawang Lampung \\ E-mail : fajarinsky18@yahoo.com
}

\begin{abstract}
ABSTRAC
The participation of the community towards the success rate of the program, the influence of motivation on the success rate of the program, and the influence of community participation and motivation together affect the success rate of the Rural Infrastructure Support Program - the National Program for Community Empowerment (RIS-PNPM) Mandiri.
\end{abstract}

\begin{abstract}
ABSTRAK
Partisipasi masyarakat terhadap tingkat keberhasilan program, pengaruh motivasi terhadap tingkat keberhasilan program, dan pengaruh partisipasi masyarakat dan motivasi secara bersama-sama berpengaruh terhadap tingkat keberhasilan program Rural Infrastruktur SupportProgram Nasional Pemberdayaan Masyarakat (RIS-PNPM) Mandiri.
\end{abstract}

Kata Kunci: Partisipasi Masyarakat, Motivasi, Keberhasilan Program

\section{PENDAHULUAN}

Rural Infrastructure Support to PNPM Mandiri Project atau yang dikenal dengan RIS-PNPM Mandiri merupakan program pemberdayaan masyarakat yang berada di bawah payung PNPM Mandiri. Program ini berupaya untuk menciptakan dan meningkatkan kualitas kehidupan masyarakat, baik secara individu maupun kelompok melalui partisipasi dalam memecahkan berbagai permasalahan yang terkait kemiskinan dan ketertinggalan desanya sebagai upaya peningkatkan kualitas kehidupan, kemandirian dan kesejahteraan masyarakat melalui Bantuan
Langsung Masyarakat (BLM). RIS-PNPM Mandiri merupakan program berbasis pemberdayaan yang bantuannya meliputi fasilitasi dan mobilisasi masyarakat dalam melakukan identifikasi permasalahan kemiskinan, menyusun perencanaan dan melaksanakan pembangunan infrastruktur desa. Tingkat keberhasilan pembangunan dalam pembangunan daerah sangat ditentukan oleh sejauh mana perencanaan pembangunan tersebut mampu melibatkan partisipasi masyarakat. Masyarakat desa sasaran merupakan pemilik kegiatan RISPNPM Mandiri sehingga masyarakat harus dapat 
memberikan dukungan dan berperan aktif selama penyelenggaraan program.

Masyarakat merupakan pelaksana utama dalam pelaksanaan program ditingkat desa, sehingga keberhasilan program ini akan sangat tergantung pada peran aktif masyarakat tersebut baik dalam proses penyiapan masyarakat, sosialiasasi, perencanaan, pelaksanaan \& pemeliharaannya.

Pengelolaan RIS-PNPM Mandiri ditingkat desa dilaksanakan oleh Organisasi Masyarakat Setempat (OMS) yang dipilih dan dibentuk oleh masyarakat dalam suatu mekanisme musyawarah desa.

Masyarakat setempat tidak hanya untuk menyelenggarakan program pembangunan, tetapi juga untuk mengelola kegiatan tersebut. Pengelolaan tersebut akan mendorong masyarakat untuk mengerahkan segala kemampuan dan potensinya demi keberhasilan program atau program tersebut.

Visi RIS-PNPM adalah terwujudnya masyarakat yang mandiri dan tersedianya infrastruktur yang mendukung produktivitas masyarakat diperdesaan secara berkelanjutan. Sedangkan misi RIS-PNPM adalah :
1. Meningkatkan
masyarakat dalam
keberdayaan
pembangunan dan pemeliharaan partisipatif.

\section{Meningkatkan akses infrastruktur pedesaan yang mendorong terwujudnya produktivitas masyarakat secara berkelanjutan.}

Partisipatif, artinya masyarakat terlibat secara aktif dalam kegiatan mulai dari proses perencanaan, pelaksanaan, pengawasan, pemeliharaan dan pemanfaatan, serta memberikan kesempatan secara luas partisipasi aktif dari kelompok miskin, hampir miskin dan kaum perempuan. Program dilaksanakan dengan pendekatan pemberdayaanan masyarakat, dimana masyarakat harus berpartisipasi dalam seluruh tahapan pelaksanaan, termasuk terlibat dalam pengawasan pada pelaksanaannya;

Adapun keberhasilan program diantaranya pelaksanaan pekerjaan fisik infrastuktur dapat selesai tepat waktu, sesuai dengan anggaran dan terpenuhinya jumlah minimal kehadiran masyarakat.

\section{METODE PENELITIAN}

\section{Partisipasi Masyarakat}

Salah satu teori partisipasi yang terkenal dan sering dipakai dalam penelitianpenelitian terkait partisipasi adalah teori dari Sherry Arnstein. Sherry Arnstein adalah yang pertama kali mendefinisikan strategi partisipasi yang didasarkan pada distribusi kekuasaan antara masyarakat (komunitas) dengan badan pemerintah (agency). Dengan pernyataannya bahwa partisipasi masyarakat identik dengan kekuasaan masyarakat (citizen partisipation is citizen power).

Fung menyatakan bahwa 'Partisipasi adalah keterlibatan aktif dari masyarakat, khususnya kelompok yang kurang mampu seperti perempuan, anak-anak, lanjut usia, penyandang cacat dandari kalangan miskin, dalam pengambilan keputusan, perencanaan, pelaksanaan, dan evaluasi kegiatan pembangunan mereka sendiri (Fung, 2002). Mircea (2011) membagi partisipasi menjadi 6 pengertian, yaitu:

1. Partisipasi adalah kontribusi sukarela dari masyarakat kepada program tanpa ikut serta dalam pengambilan keputusan.

2. Partisipasi adalah "pemekaan" (membuat peka) pihak masyarakat untuk meningkatkan kemauan menerima dan kemampuan untuk menanggapi program-program pembangunan.

3. Partisipasi adalah keterlibatan sukarela oleh masyarakat dalam perubahan yang ditentukannya sendiri. 
4. Partisipasi adalah suatu proses yang aktif, yang mengandung arti bahwa orang atau kelompok yang terkait, mengambil inisiatif dan menggunakan kebebasannya untuk melakukan hal itu.

\section{Motivasi}

Akhmad Sudrajat, M.Pd 2008 dalam artikel kumpulan teori- teori motivasi menyatakan motivasi dapat diartikan sebagai kekuatan (energi) seseorang yang dapat menimbulkan tingkat persistensi dan entusiasmenya dalam melaksanakan suatu kegiatan, baik yang bersumber dari dalam diri individu itu sendiri (motivasi intrinsik) maupun dari luar individu (motivasi ekstrinsik). Seberapa kuat motivasi yang dimiliki individu akan banyak menentukan terhadap kualitas perilaku yang ditampilkannya, baik dalam konteks belajar, bekerja maupun dalam kehidupan lainnya..

Dalam konteks studi psikologi, Abin Syamsuddin Makmun (2003) mengemukakan bahwa untuk memahami motivasi individu dapat dilihat dari beberapa indikator, diantaranya:

(1) durasi kegiatan;

(2) frekuensi kegiatan;

(3) persistensi pada kegiatan;

(4) ketabahan, keuletan dan kemampuan dalam mengahadapi rintangan dan kesulitan;

(5) devosi dan pengorbanan untuk mencapai tujuan;

(6) tingkat aspirasi yang hendak dicapai dengan kegiatan yang dilakukan;

(7) tingkat kualifikasi prestasi atau produk (out put) yang dicapai dari kegiatan yang dilakukan;

(8) arah sikap terhadap sasaran kegiatan.

Motivasi seorang individu sangat dipengaruhi oleh berbagai faktor, baik yang bersifat internal maupun eksternal. Termasuk pada faktor internal adalah : (a) persepsi seseorang mengenai diri sendiri; (b) harga diri; (c) harapan pribadi; (d) kebutuhaan; (e) keinginan; (f) kepuasan kerja; (g) prestasi kerja yang dihasilkan.
Sedangkan faktor eksternal mempengaruhi motivasi seseorang, antara lain ialah : (a) jenis dan sifat pekerjaan; (b) kelompok kerja dimana seseorang bergabung; (c) organisasi tempat bekerja; (d) situasi lingkungan pada umumnya; (e) sistem imbalan yang berlaku dan cara penerapannya.

\section{Keberhasilan Program}

Menurut pandangan lama, sebuah program dikatakan berhasil jika pembangunan diselesaikan tepat waktu, sesuai dengan anggaran dan kualitas baik. Selain itu juga memberikan kepuasan yang tinggi pada pelanggan. Untuk menentukan keberhasilan program, menurut Chan (2002) pertama kali perlu dibuat review yang komperehensif dari beberapa kriteria program yang berhasil secara general. Setelah didapatkan kriteria program sukses secara general, dilakukan modifikasi framework untuk kriteria keberhasilan program. Chan (2002) juga menjelaskan bahwa kinerja suatu tim tergantung pada kemampuan dan keahlian tim program, klien, pimpinan tim desain, dan pimpinan tim konstruksi. Manajemen program konstruksinya meliputi beberapa macam kelompok klien, desainer, suplier, sub-contraktor.

Menurut Subhan (2003) Secara umum kirteria dan cara mengukur keberhasilan dari sebuah program adalah,

a) Menentukan definisi tujuan (goal definition) yang jelas, maksudnya seberapa besar program yang akan dilaksanakan serta kebutuhan apa yang diperlukan oleh semua orang yang terlibat dalam pembuatan program.

b) Hasil dari program tersebut dapat diterima oleh pelanggan, deadline yang tepat, serta sesuai anggaran atau tidak melebihi budget.

c) Komitmen yang kuat pada suatu program, maksudnya program yang berhasil adalah program yang dapat memiliki komitmen dalam hal manajemen dan organisasi dalam sebuah program. Sesuai yang direncanakan maksudnya tidak mengambil jalan pintas dalam 
sebuah program. Terlihat dari harapanharapan yang membangundi sebuah tim yang menangani program.

d) Cakupan (Scope) program yang digarap sewajarnya, biasanya program yang berhasil memiliki cakupan (scope) yang jelas, tidak serakah dan hasilnya pun sempurna.

e) Biaya yang dikeluarkan ketika program terselesaikan tidak jauh dari rencana awal, maksudnya jangan sampai biaya yang dikeluarkan sudah besar, akan tetapi kualitas dari hasil sebuah program mengecewakan. Atau biaya yang dikeluarkan sudah banyak hasil programnya telat waktu

f) Kualitas yang baik, maksudnya ketika dilakukan proses pengujian hasil program sesuai dengan apa yang diharapkan. Jangan sampai hasil dari sebuah program cepat, tapi kualitasnya dikorbankan.

g) Ketrampilan sumber daya manusia (SDM), maksudnya diperlukan SDM yang mempunyai kompetensi yang unggul atau ahli didalam bidangnya. SDM yang mempunyai jiwa disiplin tepat waktu, dapat membuat lingkungan kerja yang kondusif, serta pekerja yang dapat diatur oleh manajer.

h) Komunikasi yang baik, maksudnya ketika tim program menjalankan sebuah program ada baiknya menjalin hubungan secara terus menerus kepada pemilik dan pengguna. Tidak menutup kemungkinan program yang berhasil adalah tim yang dapat menjalin komunikasi sesama tim

i) Resiko yang ditimbulkan dari sebuah program kecil, sebisa mungkin program yang dijalankan tidak menimbulkan resiko. Diharapkan seminimal mungkin resiko terjadi dalam sebuah program.

j) Yang terakhir hasil dari sebuah program diharapkan tidak menimbulkan suatu permasalahan baru diperusahaan dalam arti kata malah menyulitkan perusahaan dalam menjalankan kegiatan operasional perusahaan.

\section{HASIL DAN PEMBAHASAN}

Tingkat keberhasilan pembangunan dalam pembangunan daerah sangat ditentukan oleh sejauhmana perencanaan pembangunan tersebut mampu melibatkan partisipasi masyarakat. Partisipasi masyarakat berpengaruh positif terhadap tingkat keberhasilan program PNPM Mandiri.

Apabila terjadi perubahan pada partisipasi masyarakat maka tingkat keberhasilan programnya pun akan berubah. Perubahan yang terjadi searah karena kedua persamaan tersebut bertanda positif sehingga peningkatan pada partisipasi masyarakat akan membawa peningkatan pada pencapaian tingkat keberhasilan program.

Dengan kata lain semakin tinggi partisipasi masyarakat pada program PNPM maka akan semakin tercapai tingkat keberhasilan dari program tersebut. Hal sebaliknya terjadi jika partisipasi warga menurun atau lebih rendah.

Faktor motivasi juga berpengaruh positif terhadap partisipasi masyarakat dan tingkat keberhasilan program karena dalam salah satu kunci kesuksesan keberhasilan partisipasi masyarakat dapat dilihat pada adanya motivasi yang baik dari tokoh-tokoh kunci dalam masyarakat seperti para tokoh masyarakat, pihak pemerintah lokal, dan pemimpin-pemimpin masyarakat lainnya, sehingga akan ada yang dapat dijadikan panutan oleh masyarakat untuk terlibat secara maksimal dalam pelaksanaan program.

\section{KESIMPULAN DAN SARAN}

\section{Kesimpulan}

Jadi tingkat keberhasilan RIS- PNPM Mandiri di desa dipengaruhi oleh adanya partisipasi dari masyarakat dalam proses perencanaan, pelaksanaan serta 
pelestarian program PNPM Mandiri, begitu juga motivasi. Motivasi yang baik akan membantu mendorong masyarakat untuk ikut berpartisipasi sehingga program PNPM Mandiri di desa dapat terlaksana dengan baik. Hasil dari aspirasi masyarakat pada program RIS- PNPM Mandiri di desa adalah menetapkan dana bantuan digunakan untuk pembangunan infrastuktur baik jalan , drainase maupun jembatan yang diharapkan dapat mempercepat dan mempermudah para petani dalam mengangkut hasil panen sehingga diharapkan dapat meningatkan perekonomian masyarakat desa.

Berdasarkan penelitian, kondisi ini berimplikasi pada beberapa hal sebagai berikut yaitu :

1. Hendaknya permasalahan partisipasi masyarakat yang rendah dapat diatasi dengan pemilihan waktu yang tepat terhadap pelaksanaan program agar masyarakat mampu berpartisipasi secara optimal tanpa harus terbentur waktu untuk mencari nafkah.

2. Untuk permasalahan yang terkait dengan motivasi yang rendah dapat diatasi dengan rangsangan seorang pemimpin program, kepala desa, tokoh adat dan pemuka agama terhadap masyarakat agar kemauan masyarakat untuk melaksanakan kesepakatan program meningkat.

\section{Saran}

Kemiskinan, dalam hal ini melalui infrastruktur yang dibangun berdasarkan aspirasi masyarakat desa.

Peran aktif lembaga desa juga sangat diperlukan dalam penentuan program agar tepat sasaran yaitu pengentasan

\section{DAFTAR PUSTAKA}

[1] Abin Syamsuddin Makmun. 2003. Psikologi Pendidikan. PT Rosda Karya Remaja,Bandung.

[2] Akhmad Sudrajat, M.Pd. 2008 TeoriTeori Motivasi

https://akhmadsudrajat.wordpress.com/ 2008/02/06/teori-teori-

motivasi/[Accessed 1 juli 2015]

[3] Arnstein, Sherry R. 1969. A Ladder of CitizenParticipation. Journal of the American Institute of Planners. [Online] Vol. 35, No. 4, July 1969, pp. 216-224. Boston: American Institute of Planners. Retrieved February 17, 2006. [Online] Available from http://lithgowschmidt.dk/sherry-arnstein/ladder-ofcitizen-participation_en.doc [Accessed 5 Maret 2013].

[4] Chan, Albert PC. 2002. A Predictive Model for Project Succes, 351-359.

[5] Fung, Archon. 2002. Empowered Participation: Reinventing Urban Democracy. Princeton: Princeton UniversityPress.

[6] Mircea, Teodor. 2011. Community Participation and Involvement in Social Actions. Jurnal Transylvanian Review of Administrative Sciences. [Online] No. 33 E/2011,

[7] Subhan, Muhammad. 2003. Kriteria Keberhasilan Proyek. Komunitas elearning ilmu computer.com. Universitas Bina Nusantara. 